\begin{tabular}{|l|l|l|}
\hline \multicolumn{2}{|c|}{ PublisherInfo } \\
\hline \hline PublisherName & $:$ & BioMed Central \\
\hline \hline PublisherLocation & $:$ & London \\
\hline \hline PublisherImprintName & $:$ & BioMed Central \\
\hline \hline
\end{tabular}

\title{
bcl-2 and tamoxifen-induced apoptosis
}

\begin{tabular}{|l|l|l||}
\hline \multicolumn{2}{|c|}{ ArticleInfo } \\
\hline \hline ArticleID & $:$ & 3649 \\
\hline \hline ArticleDOI & $:$ & $10.1186 /$ bcr-1999-66627 \\
\hline \hline ArticleCitationID & $:$ & 66627 \\
\hline \hline ArticleSequenceNumber & $:$ & 69 \\
\hline \hline ArticleCategory & $:$ & Paper Report \\
\hline \hline ArticleFirstPage & $:$ & 1 \\
\hline \hline ArticleLastPage & $:$ & 3 \\
\hline \hline & & RegistrationDate : 1999-12-7 \\
\hline ArticleHistory & $:$ & OnlineDate \\
\hline \hline ArticleCopyright & $:$ & Current Science Ltd1999-12-7 \\
\hline \hline ArticleGrants & $:$ & \\
\hline \hline ArticleContext & $:$ & 1305811 \\
\hline \hline
\end{tabular}




\section{Keywords}

Apoptosis, bcl-2, breast cancer, p53, tamoxifen

\section{Introduction}

Tamoxifen (TAM) is commonly used for adjuvant therapy of breast cancer, and is believed to work by competing with estrogen for binding to the estrogen receptor (ER). It has been suggested that TAM may exert its anti-proliferative effects by inducing apoptosis. The $b c l-2$ family of genes are associated with apoptosis, with the gene products bcl-2, bcl- $\mathrm{X}_{\mathrm{L}}$ being inhibitors, while others such as bax are inducers of cell death. Apoptosis is controlled by the ratio of the various bcl-2 family members. Overexpression of HER2 in ER-positive MCF7 cells has been shown to suppress tamoxifen-induced apoptosis by up-regulating bcl-2 and bcl- $\mathrm{X}_{\mathrm{L}}$ protein. However, it is not known whether TAM directly modulates bcl-2, bax or bcl- $\mathrm{X}_{\mathrm{L}}$.

\section{Aims}

To investigate whether TAM-induced apoptosis is related to the expression of $b c l-2$ family genes and p53 protein.

\section{Comments}

Expression of bcl-2 appears to be a favourable prognostic factor and predictor of response to endocrine therapy. Frequent co-expression with ER may indicate that the pathways are closely linked in breast epithelial cells, and reflects the importance of sensitivity to estrogens and apoptosis in the development and progression of breast cancer. The improved response to hormonal treatment of bcl-2-positive tumors may be explained by TAM-induced apoptosis via down-regulation of bcl-2 levels in these cells. The lack of association between tamoxifen and other $b c l-2$ family members described here may explain the reported lack of prognostic and predictive reliability of these gene products. 


\section{Methods}

MCF-7 breast cancer cells were exposed to TAM, and apoptosis measured by an enzyme-linked immunosorbent assay (ELISA). Semi-quantitation of bcl-2, bax and bcl- $\mathrm{X}_{\mathrm{L}}$ levels were performed using reverse transcriptase polymerase chain reaction (RT-PCR). Protein quantitation for bcl-2, bax, bcl- $\mathrm{X}_{\mathrm{L}}$ and p53 was carried out by western blot analysis.

\section{Results}

TAM-induced apoptosis in MCF-7 cells was seen to be time- and concentration-dependent. TAM decreased the expression of bcl-2 mRNA and protein in a dose dependent manner. Expression of bax and bcl-X $\mathrm{L}$ mRNA and protein were unchanged with TAM treatment. The time-dependent downregulation of bcl-2 protein correlated with apoptosis. TAM did not affect p53 protein levels.

\section{Discussion}

The data presented here demonstrate that TAM can induce apoptosis in a time- and concentrationdependent manner by modulating bcl-2 levels in breast cancer cells. This down-regulation of bcl- 2 was not accompanied by alterations in bax, bcl-X $\mathrm{X}_{\mathrm{L}}$ or $\mathrm{p} 53$ levels.

\section{References}

1. Zhang G-J, Kimijima I, Onda M, Kanno M, Sato H, Watanabe T, Tsuchiya A, Abe R, Takenoshita S: Tamoxifen-induced apoptosis in breast cancer cells relates to down-regulation of bcl-2, but not bax and bcl-XL, without alteration of p53 protein levels. Clin Cancer Res. 1999, 5: 2971-2977. 